\title{
Usulan Perbaikan Proses Produksi Tas Ransel Untuk Meminimalkan Kecacatan Produk Dengan Metode Six Sigma (Studi Kasus: UD Diechi )
}

\author{
Mohammad Erry $^{(1)}$, Pregiwati Pusporini ${ }^{(2)}$, Dzakiyah Widyanigrum ${ }^{(3)}$ \\ ${ }^{1}$ Mahasiswa Teknik Industri, Fakultas Teknik, Universitas Muhammadiya Gresik \\ ${ }^{2,3}$ Dosen Teknik Industri, Fakultas Teknik, Universitas Muhammadiyah Gresik Jl. Sumatera No. \\ 101 GKB-Gresik 61121. \\ e-mail : Erry372@gmail.com
}

\begin{abstract}
ABSTRAK
Salah satu perusahaan yang belum menerapkan pengendalian kualiatas adalah UD Diechi. UD Diechi didirikan pada tahun 19-09-1991 oleh bapak H. Tahal dan mampu memproduksi hingga 1000-2000 Unit Tas per bulan. UD Diechi terletak di kelurahan pekauman Jalan KH. Abdul Karim No 95, Gresik.adalah Usaha Micro Kecil dan Menengah yang bergerak di industri manufaktur memproduksi berbagai jenis Tas diantaranya adalah : Tas Anak, Tas Ransel, Tas Laptop, Tas Pinggang, dan juga Tas Pesanan Khusus dan Dll. Untuk pemasarannya UD. Diechi menjual produknya dari ritel ke ritel dan menjual produknya dari pemesanan konsumen serta melalui sosial media. Bertambahnya permintaan maka penyebarannya mulai merambah ke kota lain seperti Surabaya, Sidoarjo, Mojokerto dan kota sekitar laninnya. Dalam hal ini memilih Tas Ransel untuk dilakukan adalah dikarenakan Produk Tas Ransel paling sering di produksi dan dicari konsumen serta memiliki kecacaatan yang cukup banyak. Pengendalian kualitas yang dilakukan pada UD Diechi belum baik yang terbukti dengan adanya produk cacat di batas toleransi dan belum mampu mengidentifikasikan faktor kecacatan dan penyebab kecacatan secara ideal. Kondisi saat ini UD Diechi belum melakukan tindakan apapun berkaitan dengan usaha meningkatkan kualitas produk. Dengan penelitian ini diharapkan sebagai bahan pertimbangan perusahaan untuk mengambil konsep mengenai pengendalian kualitas dengan menggunakan metode Six Sigma. Untuk memahami strategi pengendalian kualitas bagi UD Diechi yaitu menurunkan jumlah kecacatan yang terjadi, maka dicoba untuk mengadopsi metode Six Sigma dalam menganalisis dan memperbaiki pengendalian kualitas. Dari hasil penelitian diketahui data hasil produksi UD. Diechi pada bulan Januari - Juni 2018 didapat nilai DPMO (Defect per Million opportunity) dan nilai Sigma Untuk perhitungan DPMO data jenis Atribut yaitu dalam 1.000 .000 pcs terdapat 688Defect Atribut yang bisa dihasilkan dan diperoleh nilai Sigma sebesar 3,7.
\end{abstract}

Kata kunci : Six Sigma, Dmai, Copq, Fmea, Fish Bone

1. Pendahuluan

Six Sigma adalah sistem yang komprehensif dan fleksibel untuk mencapai, mempertahankan dan memaksimalkan sukses bisnis. Six Sigma secara unik dikendalikan oleh pemahaman yang kuat terhadap fakta, data, dan analisis statistik, serta perhatian yang cermat untuk mengolah, memperbaiki, dan menanamkan proses bisnis. Menurut Gaspersz (2005) Six Sigma adalah suatu visi peningkatan kualitas menuju target 3,4 kegagalan perjuta kesempatan untuk setiap transaksi produk barang dan jasa. Jadi Six Sigma merupakan suatu metode atau teknik dalam hal pengendalian dan peningkatan produk dimana sistem ini sangat komprehensif dan fleksibel yang merupakan terobosan baru dalam bidang manajemen kualitas untuk mencapai, mempertahankan, dan memaksimalkan kesuksesan suatu usaha.

Terdapat salah satu usaha Tas yaitu UD Diechi yang berada di desa terletak di kelurahan pekauman Jalan KH. Abdul Karim No 95, Gresik.adalah Usaha Micro Kecil dan Menengah yang bergerak di industri manufaktur memproduksi berbagai jenis Tas diantaranya adalah : Tas Anak, Tas Ransel, Tas Laptop, Tas Pinggang, dan juga Tas Pesanan Khusus dan Dll.

Dapat bertahan dalam industri yang bersaing seperti saat ini merupakan suatu hal yang mengejutkan bagi UD Diechi, karena saat ini tantangan yang dihadapi oleh indutri ini tidak hanya dari pesaing lokal, tetapi juga bersaing dengan pasar internasional atau produk impor. Ditengah persaingan tersebut UD Diechi tetap dapat bertahan, dan juga berkembang, Hal tersebut merupakan suatu hal yang menarik untuk diteliti.

pengelasan pagar, dapat dilihat pada gambar 1.2. 


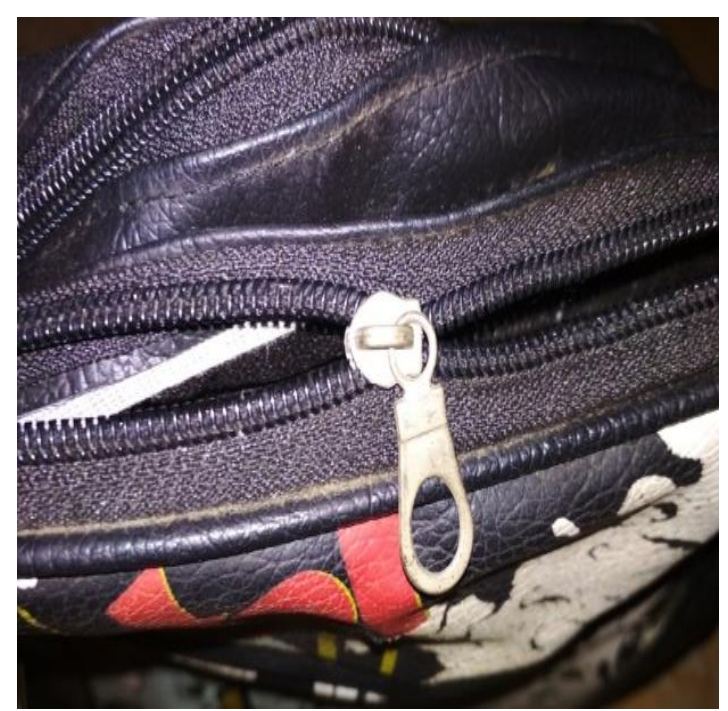

Gambar 1.2 Produk cacat Resleting macet.

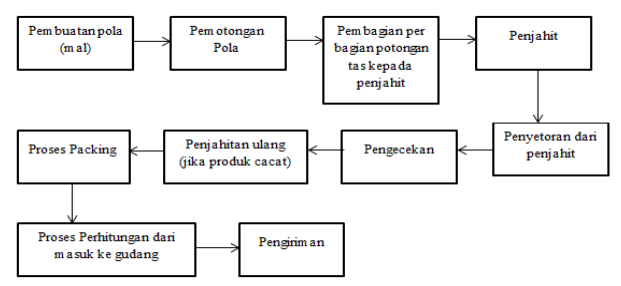

Berdasarkan gambar 1.2 Dengan adanya kecacatan pada proses produksi tas ransel UD. Diechi perlu melakukan tindakan perbaikan pada produk cacat tas ransel. dampaknya UD Diechi menambah biaya untuk proses perbaikan ulang. Dengan adanya produk cacat yang melebihi batas toleransi pada UD Diechi maka biaya produksi yang di keluarkan akan lebih banyak sehingga harga pokok produksi akan lebih tinggi, dan harga produksi yang tinggi menyebabkan harga jual menjadi tinggi pula. Produk akan kalah bersaing dengan perusahaan sejenis yang mempunyai harga jual lebih murah dan kualitas yang lebih baik untuk jenis produk yang sama. salah satu metode yang dapat digunakan untuk mengendalikan kualitas produksi diantaranya metode Six Sigma. gambar 1.3.

\begin{tabular}{|c|c|c|c|c|c|c|c|}
\hline Tahm & Hari & Bulan & $\begin{array}{l}\text { Jumlah } \\
\text { produk }\end{array}$ & Lusin & $\begin{array}{c}\text { Produk } \\
\text { Bagus }\end{array}$ & Cacat & $\begin{array}{l}\text { persentase } \\
\text { cacat } \%\end{array}$ \\
\hline \multirow{9}{*}{2018} & 31 & Januari & 1440 & 120 & 1317 & 123 & 8,54 \\
\hline & 28 & Februari & 1200 & 100 & 1114 & 86 & 7,16 \\
\hline & 31 & Maret & 1800 & 150 & 1690 & 110 & 6,11 \\
\hline & 30 & April & 1800 & 150 & 1654 & 146 & 8,11 \\
\hline & 31 & Mei & 1440 & 120 & 1315 & 125 & 8,68 \\
\hline & 30 & Juni & 1440 & 120 & 1307 & 137 & 9,51 \\
\hline & & Total & 9120 & 760 & 8397 & 727 & \\
\hline & & Rata-rata & 1520 & 126,6 & 1399 & 121,1 & \\
\hline & \multicolumn{4}{|c|}{ persentase kecacatan $\%$} & & $7,97 \%$ & \\
\hline
\end{tabular}

Gambar 1.3 Data Produksi UD Diechi

Berdasarkan permasalahan tersebut untuk menyelesaikan permasalahan maka metode yang tepat digunakan yaitu Six Sigma adalah sistem yang komprehensif dan fleksibel untuk mencapai, mempertahankan dan memaksimalkan sukses bisnis. Six Sigma secara unik dikendalikan oleh pemahaman yang kuat terhadap fakta, data, dan analisis statistik, serta perhatian yang cermat untuk mengolah, memperbaiki, dan menanamkan proses bisnis. Menurut Gaspersz (2005). Membuat peneliti ingin melakukan penelitian tentang "Usulan Perbaikan Proses Produksi Tas Ransel Untuk Meminimalkan Kecacatan Produk Dengan Metode Six Sigma Analisis (Studi Kasus: UD Diechi)".

\subsection{Rumusan Masalah}

Berdasarkan latar belakang diatas maka dapat diambil rumusan dari permasalahan yang akan dibahas dalam penelitian ini. Rumusan masalah sebagai berikut:

1. Apa faktor penyebab terjadinya cacat (defect) pada proses produksi tas ransel?

2. Berapa nilai Defect per Million Opportunity (DPMO) dan nilai sigma?

3. Bagaimana rancangan usulan perbaikan yang tepat untuk mengurangi kecacatan produk tas ransel?

\subsection{Tujuan Penelitian}

Adapun tujuan yang ingin dicapai dalam penelitian tugas akhir ini adalah sebagai berikut:

1. Mengetahui faktor-faktor apa yang menyebabkan terjadinya cacat (defect) pada produk Tas ransel.

2. Menghitung nilai Defect per Million Opportunity (DPMO), nilai sigma saat ini, dan Cost of Poor Quality (COPQ).

3. Memberi usulan rancangan perbaikan untuk mengurangi jumlah produk cacat (defect) tas ransel. 


\subsection{Manfaat Penelitian}

Penelitian ini diharapkan dapat memberikan manfaat yang besar yaitu sebagai berikut:

1. Dapat dijadikan sebagai pertimbangan perusahaan dalam pelaksanaan pengendalian cacat terhadap produk tas ransel yang diproduksi. Adanya penelitian ini sebagai bahan acuan usulan perbaikan tingkat kecacatan produk melalui metode Six Sigma.

2. Diharapkan dengan berkurangnya produk defect maka good product akan meningkat. Maka kerugian bisa terkurangi dan keuntungan perusahaan akan meningkat.

\subsection{Batasan Masalah}

Batasan masalah yang digunakan dalam memfokuskan penelitian tugas akhir ini adalah:

1. Data yang diambil adalah historis perusahaan mulai bulan Januari sampai Juni 2018.

2. Penelitian hanya dilakukan pada proses produksi Tas Ransel karena produk Tas Ransel adalah produk yang sering di produksi dan dipesan konsumen.

3. Data perhitungan Hanya sebatas Data Atribut.

\subsection{Asumsi - Asumsi}

Asumsi - asumsi yang digunakan dalam penelitian tugas akhir ini adalah:

1. Tidak dilakukan perubahan terhadap fasilitas produksi dan peralatan produksi.

2. Karakteristik kualitas yang diambil yakni variabel (yang diukur) dan atribut (yang diamati langsung).

3. Kondisi mesin pada saat pada proses produksi dalam kondisi baik.

\section{Tinjauan Pustaka}

Menurut Gaspersz (2005) six sigma merupakan suatu visi peningkatan kualitas menuju target 3,4 kegagalan per sejuta kesempatan (Defect Per Million Opportunity) untuk setiap transaksi (barang/jasa), dan merupakan suatu kegiatan menuju kesempurnaan.

Berikut adalah aspek kunci yang perlu diperhatikan dalam aplikasi konsep six sigma (Gaspersz)

1. Identifikasi pelanggan.

2. Identifikasi produk
3. Identifikasi kebutuhan dalam memproduksi produk untuk pelanggan.

4. Defisini proses.

5. Menghindari kesalahan dalam proses dan menghilangkan semua pemborosan yang ada.

6. Tingkat proses secara terus menerus menuju target six sigma.

Pengertian pengendalian kualitas menurut pendapat Handoko (2000) merupakan upaya mengurangi kerugian-kerugian akibat produk rusak dan banyaknya sisa produk atau scrap. Pengertian pengendalian kualitas menurut pendapat Assauri (1999) adalah merencanakan dan melaksanakan cara yang paling ekonomis untuk membuat sebuah barang yang akan bermanfaat dan memuaskan tuntutan konsumen secara maksimal.

Berdasarkan pemaparan diatas, yang dimaksud dengan pengendalian kualitas merupakan alat yang paling penting bagi manajemen produksi untuk menjaga, memelihara, memperbaiki dan mempertahankan kualitas produk agar sesuai dengan standar yang telah ditetapkan.

Pengendalian merupakan alat bagi manajemen untuk memperbaiki produk bila diperlukan, mempertahankan kualitas produk yang sudah tinggi dan mengurangi jumlah produk yang rusak. Pengertian pengendalian kualitas menurut pendapat beberapa ahli yaitu sebagai berikut:

Pengertian pengendalian kualitas menurut pendapat Montgomery (1990) merupakan aktivitas keteknikan dan manajemen yang dengan aktivitas itu kita ukur ciri-ciri kualitas produk, membandingkan dengan spesifikasi atau persyaratan, dan mengambil tindakan penyehatan yang sesuai apabila ada perbedaan antara penampilan yang sebenarnya dan yang standar. 


\section{Metodologi Penelitian}

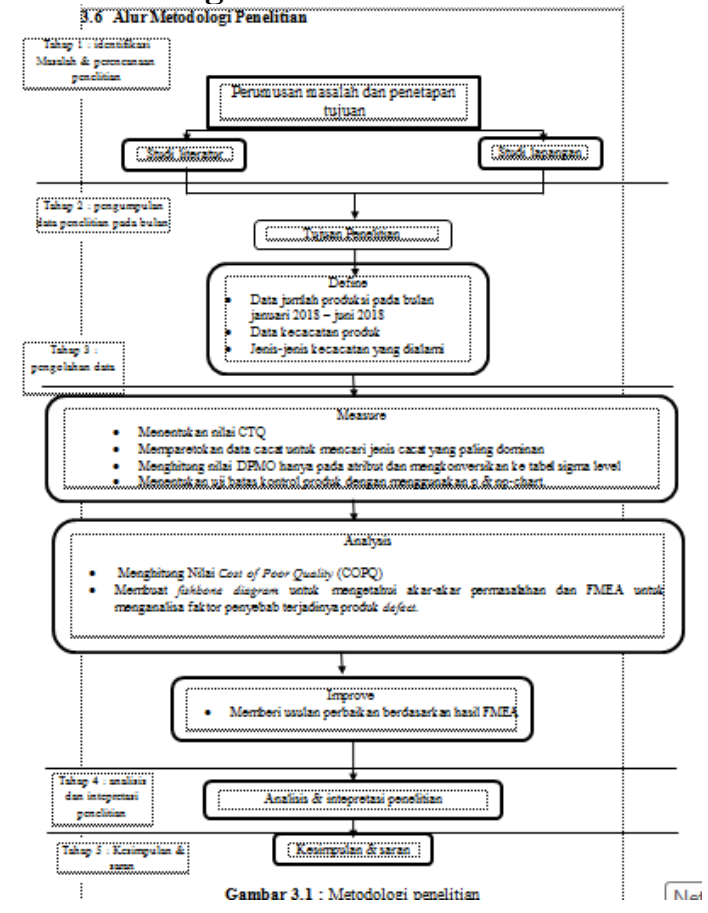

\section{Pengumpulan dan Pengolahan Data 4.1Pengumpulan Data}

Pengumpulan data pada penelitian ini adalah sebagai berikut:

1. Wawancara

Wawancara dilakukan dengan karyawan pekerja UD Diechi.

2. Penyusunan Desain Kuesioner

Terdiri dari lima faktor penilaian dan setiap faktor terdiri dari empat subfaktor, dengan menggunakan skala likert 1-5 untuk mengisinya dimana jika memberikan jawaban paling negatif atau sangat tidak setuju diberikan nilai (1) dan jika memberikan jawaban positif atau sangat baik diberikan nilai (5).

3. Penyusunan Desain Checklist

Desain checklist tersebut mengadopsi pada penelitian sebelumnya (Giovani, 2012). Desain Checklist digunakan untuk mengobservasi langsung ke UD Diechi.

4. Data Historis Jumlah Kecacatan Tas Ransel

Data historis tersebut Dari Bulan Januari Juni 2018,

5. Gambar atau foto pekerja Gambar foto pekerja pada saat bekerja dilUD Diechi.

\subsection{Pengolahan Data}

Menurut Nurullah (2014), Langkahlangkah yang dilakukan dalam pengerjaan dengan menggunakan metode six sigma melalui tahapan DMAI, sebagai berikut :

1. Tahap Define (D)

Pada tahap define akan dijelaskan dengan menggunakan diagram alir SIPOC yang merupakan akronim 5 elemen utama dalam sistem pengendalian kualitas yaitu SupplierInput-Process-Outputs-Customers.

2. Tahap Measure (M)

Terdapat dua hal utama dalam Measure Phase, yaitu : identifikasi Critical to Quality (CTQ) dan Perhitungan nilai DPMO dan Nilai Sigma.

3. Tahap Analyze (A)

Pada tahap ini dilakukan penentuan akar permasalahan dan sumber penyebab timbulnya cacat. Salah satu cara untuk mengetahui timbulnya cacat yaitu dengan menggunakan diagram sebab akibat (Fishbone diagram) dan FMEA (Failure Mode and Effect Analyze).

4. Tahap Improve (I)

Pada tahap improve akan dilakukan tindakan perbaikan untuk mengatasi masalah kegagalan potensial. Tindakan perbaikan yang dilakukan untuk mengatasi hal tersebut adalah mengetahui parameter yang berpengaruh terhadap terjadinya cacat. Selanjutnya akan disusun Design of Experiment, yaitu dengan menggabungkan faktor yang paling berpengaruh.

\subsubsection{Define}

Satu tantangan utama yang dihadapi dalam program peningkatan kualitas adalah mendefinisikan kriteria pemilihan proyek Six Sigma, dimana pelaksanaan proyek ini harus memiliki mannfaat dan kriteria-kriteria yang dijadikan pedoman. Pemilihan proyek terbaik adalah berdasarkan terhadap identifikasi proyek yang terbaik atau sepadan dengan kebutuhan, kababilitas, dan tujuan organisasi yang sekarang. Secara umum proyek Six Sigma yang terpilih harus mampu memenuhi kategori-kategori antara lain: memberikan hasil dan manfaat bagi bisnis, kelayakan dan memberikan dampak positif bagi organisasi. Adapun tujuan dari pelaksanaan project six sigma ini yaitu memberikan usulan rancangan perbaikan yang tepat untuk mengurangi cacat (defect) dengan memperbaiki faktor-faktor 
yang menjadi penyebab munculnya kecacatan produk Tas Ransel.

\subsubsection{Measure}

Pada tahap measure langkah-langkah yang dilakukan adalah:

1. Menetapkan karakteristik kualitas (CTQ).

2. Melakukan pengumpulan data (data produksi, data cacat) pada bulan Januari 2018 sampai Juni 2018.

3. Mengetahui jenis cacat yang paling dominan dengan mengunakan diagram Pareto.

4. Menghitung nilai DPMO dan mengkonversikan ke perhitungan sigma level.

\section{CTQ}

Menentukan titik Critical to Quality (CTQ) dari jenis-jenis Produk Defect, sebagai berikut:

\section{a. Data Variable (yang terukur)}

1. Ukuran : jenis cacat untuk sebuah ukuran yang tidak sesuai dengan permintaan konsumen.

\section{b. Data Atribut (yang diamati langsung)}

1. Jahitan Tidak Rapi : jenis cacat yang diamati dan terlihat adanya benang yang tidak rapi.

2. Resleting Rusak : jenis cacat yang diamati dan terlihat adanyan kerusakan dibagian resleting.

3. Tali Bisbane Robek : jenis cacat yang diamati dan terlihat adanya tali bisbane robek.

4. Logo Merk : jenis cacat yang diamati dan terlihat adanya bentuk logo merk yang tidak sesuai.

5. Sablon : jenis cacat yang diamati dan terlihat adanya sablon yang tidak sesuai.

6. Kain Bernoda : jenis cacat yang diamati dan terlihat adanya kain bernoda.

7. Clip Penjepit Rusak : jenis cacat yang diamati dan terlihat Clip penjepit rusak.

\subsubsection{Data Cacat}

Berikut data jenis-jenis kecacatan produk yang terjadi pada bulan Januari sampai Juni 2018, dapat dilihat pada gambar 1.4

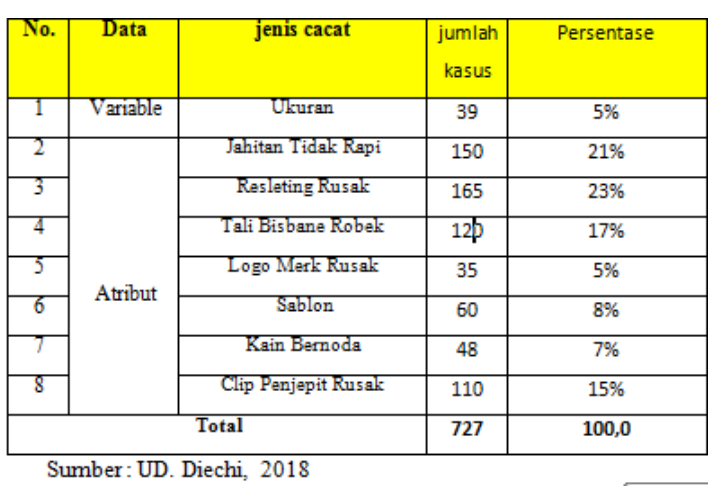

\subsubsection{Diagram Pareto}

Untuk mengetahui jenis kecacatan yang dominan dengan menggunakan diagram pareto dibawah ini :

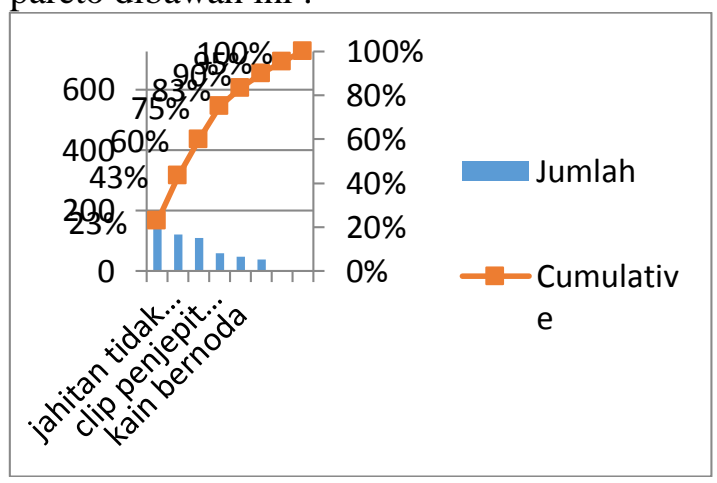

Berdasarkan gambar 4.5 bisa dilihat untuk Defect terbesar terdapat pada jenis cacat Resleting Macet (23\%), Jahitan Tidak Rapi (21\%), Tali Bisbane Robek (17\%), Clip Penjepit Rusak (15\%), Sablon (8\%), Kain Bernoda (7\%), Ukuran (5\%), Logo Merk Rusak (5\%).

\subsubsection{Menghitung DPMO}

Defect per Million Opportunity (DPMO) adalah ukuran kegagalan dalam program peningkatan kualitas six sigma yang menunjukkan kegagalan per sejuta kesempatan. Target dari pengendalian kualitas six sigma motorola yang diproduksi, tapi diinterpretasikan sebesar 3,4 DPMO seharusnya tidak diinterpretasikan sebagai 3,4 unit output yang cacat dari sejuta unit output yang diproduksi, tetapi diinterpretasikan sebagai dalam satu unit produk tunggal terdapat rata-rata kesempatan untuk gagal dari suatu karakteristik CTQ (Critical to Quality) adalah hanya 3,4 kegagalan per sejuta kesempatan (DPMO). Dapat dilihat gambar 1.5 


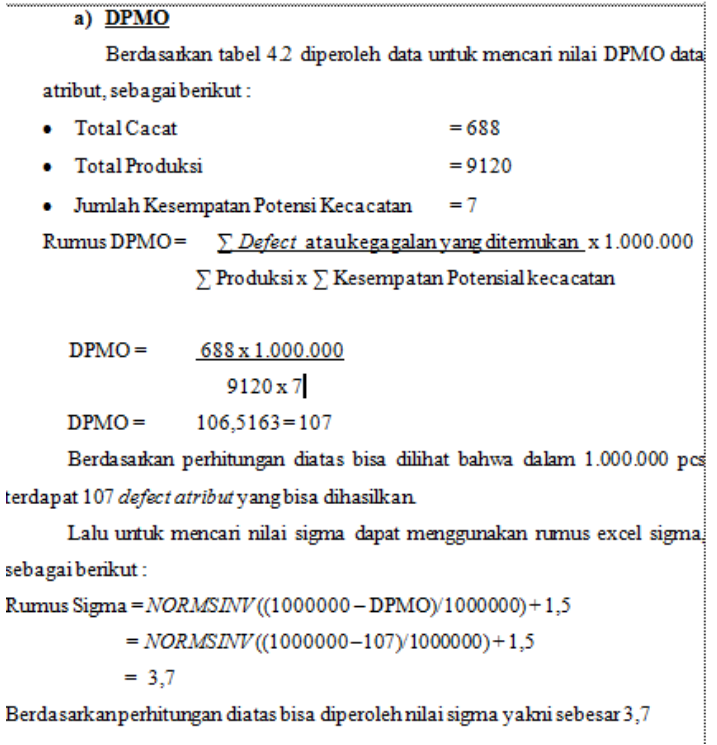

\subsubsection{Analyze}

Tahap ini merupakan tahap melakukan penentuan akar permasalahan dan sumber penyebab timbulnya cacat produk. Analyze merupakan langkah operasional ketiga dalam program peningkatan kualitas six sigma. Pada tahap ini perlu melakukan beberapa hal yaitu :

a. Mengkonversi banyak kegagalan kedalam biaya kegagalan kualitas (Cost of Poor Quality).

b. Mengidentifikasi sumber dan akar penyebab kecacatan dan kegagalan.

\subsubsection{Menghitung Nilai Cost Of Poor Quality (COPQ)}

Cost of Poor Quality (COPQ) adalah Biaya yang timbul akibat Kualitas Buruk atau kegagalan produk yang tidak memenuhi standar pelanggan (Customer). Perusahaan yang mampu memperbaiki kualitasnya dan mengeliminasi terjadi biaya COPQ ini akan dapat meningkatkan Laba Perusahaan sehingga memiliki keunggulan dalam bersaing dengan kompetitornya.

\begin{tabular}{|c|l|r|}
\hline$N_{0}$ & $\begin{array}{c}\text { Keterangan Biaya Kegagalan pada Bulan Januari } \\
\text { sampai Juni 2018 }\end{array}$ & Biaya (Rp) \\
\hline $\mathbf{1}$ & Biaya pembelianMateial & $\mathrm{Rp} 35.000 .600$ \\
\hline $\mathbf{2}$ & Biaya gajikaryawan & Rp20.000.(000 \\
\hline $\mathbf{3}$ & Biaya Perawatan Mesin & Rp5.000.0@0 \\
\hline & Total Biaya Kegagalan & Rp.10.000:00 \\
\hline & Total Penjualan & Rp.85.000\$00 \\
\hline & Prosentase Kegagalan terhadap total penjualan (\%) & 11,7 \\
\hline
\end{tabular}

\subsubsection{Failure Mode and Effect Analysis (FMEA)}

FMEA dibuat berdasarkan data hasil wawancara serta diskusi dengan tim project Six Sigma di UKM UD. Diechi dengan diambil nilai rata-rata tiap item. Kolom deskripsi proses menunjukkan proses terjadinya kegagalan proses, kolom mode kegagalan menunjukkan jenis kegagalan yang terjadi, kolom efek kegagalan menunjukkan akibat yang ditimbulkan jika terjadi mode kegagalan. Dapat dilihat hasil FMEA pada gambar $\quad 1.6$

\begin{tabular}{|c|l|c|c|c|}
\hline No. & \multicolumn{1}{|c|}{ Penyebab Kegagalan } & $\begin{array}{c}\text { Efek } \\
\text { Kegagalan }\end{array}$ & RPN & Rangking \\
\hline 1 & Karyawan Kurang Jeli & $\begin{array}{c}\text { Jahitan Tidak } \\
\text { Rapi }\end{array}$ & 384 & \\
\hline 2 & Metode Penyablonan Kurang Tepat & Sablon & 384 & \\
\hline 3 & Metode Pemilihan Bahan Kurang Bagus & $\begin{array}{c}\text { Resleting } \\
\text { Macet }\end{array}$ & 343 & \\
\hline 4 & Metode pemilihan bahan kurang Tepat & $\begin{array}{c}\text { Tali Bisbane } \\
\text { Robek }\end{array}$ & 240 & \\
\hline 5 & Perlu Diadakan Inspeksi Ulang & $\begin{array}{c}\text { Clip Penjepit } \\
\text { Rusalk }\end{array}$ & 240 & \\
\hline 6 & Pemotongan Tidak Tepat & Ukuran & 210 & \\
\hline 7 & Bahan Material Tidak Bagus & $\begin{array}{c}\text { Logo Merk } \\
\text { Rusak }\end{array}$ & 210 & \\
\hline 8 & Perlu diadakan Inspeksi & Kain Bernoda & 180 & \\
\hline
\end{tabular}

\subsubsection{Improve}

Pada tahap improve ini diterapkan suatu rencana tindakan peningkatan kualitas six sigma melalui perbaikan terhadap sumbersumber penyebab terjadinya defect product. Rencana perbaikan dilakukan terhadap segala sumber yang berpotensi untuk menciptakan defect product berdasarkan cause and effect diagram, prioritas tindakan perbaikan yang didasarkan pada nilai RPN hasil dari perhitungan FMEA yang didiskusikan dan hasil dari penyebaran kuisioner dengan Tim Project Six Sigma.

\section{ANALISIS DAN INTERPRETASI \\ DATA}

5.1 Define :

Pengumpulan Data Defect Produk dimulai pada bulan Januari sampai Juni 2018 adapaun jumlah produk defect pada produk tas ransel selama 6 bulan adalah 727 (pcs) dari total produksi 9120 (pcs) atau memiliki nilai cacat sebanyak $7,97 \%$.

\subsection{Measure :}

\section{a. Data Variable (yang terukur)}


1. Ukuran : jenis cacat untuk sebuah ukuran yang tidak sesuai dengan permintaan konsumen.

b. Data Atribut (yang diamati langsung)

1. Jahitan Tidak Rapi : jenis cacat yang diamati dan terlihat adanya benang yang tidak rapi.

2. Resleting Rusak : jenis cacat yang diamati dan terlihat adanyan kerusakan dibagian resleting.

3. Tali Bisbane Robek : jenis cacat yang diamati dan terlihat adanya tali bisbane robek.

4. Logo Merk : jenis cacat yang diamati dan terlihat adanya bentuk logo merk yang tidak sesuai.

5. Sablon : jenis cacat yang diamati dan terlihat adanya sablon yang tidak sesuai.

6. Kain Bernoda : jenis cacat yang diamati dan terlihat adanya kain bernoda.

7. Clip Penjepit Rusak : jenis cacat yang diamati dan terlihat Clip penjepit rusak.

\subsection{Analyze :}

diperoleh nilai RPN tertinggi yakni 384 dengan penyebab kegagalan dengan penyebab kegagalan defect adalah Jahitan Tidak Rapi merupakan jenis defect product Jahitan Tidak Rapi yang dijadikan prioritas utama untuk segera dilakukan perbaikan.

\subsection{Improve :}

Untuk tahap Improve diberikan usulan perbaikan dengan mebuat SOP untuk masingmasing mesin dan memberikan kartu kendali untuk pengecekan mesin produksi agar lebih diperjelas prosedur pengecekanya dan lebih terkontrol kondisi mesin.

\section{Kesimpulan Dan Saran \\ 6.1 Kesimpulan}

Untuk perhitungan DPMO data jenis Atribut yaitu dalam 1.000 .000 pcs terdapat 688Defect Atribut yang bisa dihasilkan dan diperoleh nilai Sigma sebesar 3,7.

\section{Daftar Pustaka}

(Susetyo, Winarni dan Hartanto, 2011), "Aplikasi Six Sigma DMAIC Dan Kaizen sebagai metode pengendalian dan perbaikan kualitas produk" Teknologi, vol. 4, 2011

Gaspersz, Vincent. 2002, “ Pedoman Implementasi Program Six Sigma Terintegrasi dengan ISO 9001, 2000,
$M B N Q A$ dan HACCP ", PT. Gramedia Pustaka Utama, Jakarta.

Hidayat, Anang. 2007. Strategi Six Sigma. PT. Elex Media Komputindo. Jakarta.

(American Herritage Dictionary, 1996) "Kualitas; sesuatu yang tidak dapat dipisahkan dari karakteristik, derajat, atau nilai-nilai dari suatu keunggulan".

Handoko, T. Hadi.2000. Dasar-dasar Manajemen Produksi dan Operasi. Yogyakarta:BPFE.

Montgomery,D.C. 1990. Pengantar Pengendalian Kualitas Statistik. Alih bahasa. Zanzawi. Yogjakarta.UGM.

Assauri, 1999. Manajemen Produksi. Edisi Revisi. LPFEUL. Jakarta. E. Wood.

Pande, dkk. 2002. The Six Sigma Way Bagaimana GE, Motorola \& Perusahaan Terkenal Lainnya Mengasah Kinerja Mereka. ANDI. Yogyakarta.

Feigenbaum,2002 . Kendali Mutu Terpadu. Edisi ketiga. Erlangga.

Gasperz, Vincent. 2005. Total Quality Management. PT. Gramedia Pustaka Utama. Jakarta.

Assauri, 1999. Manajemen Produksi. Edisi Revisi. LPFEUL. Jakarta.

Ahyari, 1990. Manajemen Produksi . Edisi keempat. Jilid kedua. BPFE. Yogjakarta.

Ahyari, 1990. Manajemen Produksi . Edisi keempat. Jilid kedua. BPFE. Yogjakarta.

Latief, Yusuf dkk. 2009. Penerapan Pendekatan Metode Six Sigma Dalam Penjagaan Kualitas Pada Proyek Konstruksi. Dalam jurnal Makara, Teknologi, Volume 13, No. 2. Hal 6772 Depok: Universitas Indonesia.

Nurullah, Amalia ( Institut Teknologi Nasional Bandung) ; Fitria, Lisye; Adianto, Hari (2014), Perbaikan Kualitas Benang 20S Dengan Menggunakan Penerapan Metode Six Sigma-DMAIC Di PT. Supratex. REKA INTEGRA Vol. 